\title{
Paideusis
}

\section{"On Virtue Ethics" (Rosalind Hursthouse)}

\section{Paul O'Leary}

Volume 15, Number 1, 2006

URI: https://id.erudit.org/iderudit/1072699ar

DOI: https://doi.org/10.7202/1072699ar

See table of contents

Publisher(s)

Canadian Philosophy of Education Society

ISSN

0838-4517 (print)

1916-0348 (digital)

Explore this journal

Cite this review

O'Leary, P. (2006). Review of ["On Virtue Ethics" (Rosalind Hursthouse)].

Paideusis, 15(1), 107-111. https://doi.org/10.7202/1072699ar

This document is protected by copyright law. Use of the services of Erudit (including reproduction) is subject to its terms and conditions, which can be viewed online.

https://apropos.erudit.org/en/users/policy-on-use/
This article is disseminated and preserved by Érudit.

Érudit is a non-profit inter-university consortium of the Université de Montréal, Université Laval, and the Université du Québec à Montréal. Its mission is to promote and disseminate research.

https://www.erudit.org/en/ 


\title{
Review of
}

\section{On Virtue Ethics}

by Rosalind Hursthouse, Oxford: Oxford University Press, 1999

\author{
PAUL O'LEARY \\ University of Western Ontario
}

\section{A Neo-Aristotelian Education}

Traditional virtue ethics characteristically treats a range of topics which seldom, if ever, form the central concerns of various versions of deontology and utilitarianism. These topics include such items as moral motivation, moral character, moral education, moral wisdom, friendship and family relationships, the role of the emotions in the moral life, as well as questions about what sort of person one should be and how one should live. But the extent to which virtue ethics forms a distinctive category of ethical theory is complicated, not only by the fact that deontologists and utilitarians continue to make revisions to their theories which take into account standard objections made on behalf of virtue ethics, but also because there is more than one version of virtue ethics. So where Aristotle provides us with one brand of virtue ethics, Nietzsche gives us another, and the differences between them can be as significant as the difference between any one of them and some particular deontological or utilitarian theory. Such complications then should serve as warning shots across the bow of any attempt to give a short and quick answer to the question "What is virtue ethics?" What is needed instead is a detailed concrete working out of a particular version of a virtue ethic. Then we can see how it differs from or is similar to a particular version of deontology or utilitarianism.

It is with these matters in mind that Rosalind Hursthouse in her new book, On Virtue Ethics, explores a particular virtue based ethical theory; a theory which she describes as neo-Aristotelian. Obviously her approach has its roots in Aristotle's Nicomachean Ethics, but nonetheless deserves the "neo," not only because it does not share Aristotle's views about slavery and women, but also because the standard list of virtues includes items not found in Aristotle's list (e.g., charity and benevolence.) Moreover, contemporary ethical theory needs to consider issues about which Aristotle had little or nothing to say (e.g., can an Aristotelian ethical naturalism survive sceptical criticisms of it?) In what follows I want to consider certain aspects of Hursthouse's neo-Aristotelianism, especially as they bear upon our conception of moral education.

\section{Right Action}

One of Kohlberg's objections to a moral education based on the virtues is that recognition of a trait as a virtue provides no guidance as to what one ought to do. So even though we may agree that honesty is a genuine virtue, doing so does not help determine whether, for example, one ought or ought not to tell a friend who has been seriously injured in a car accident that the accident had killed the rest of her family. For Kohlberg, knowing the right thing to do is a matter of appealing to a defensible principle rather than, as an agent-centred virtue ethics would have it, appealing to what a virtuous agent would

(C) Copyright 2006. The author, Paul O'Leary, assigns to Paideusis the right of first publication and educational and non-profit institutions a non-exclusive license to use this document for personal use and in courses of instruction provided that the article is used in full and this copyright statement is reproduced. Any other usage is probibited without the express permission of the author. 
characteristically do in the circumstances.

Although Hursthouse does not mention Kohlberg, his claim that the virtues cannot specify right action is taken by her as a characteristic objection made by critics of virtue ethics. But in making the first premiss of a virtue ethics an agent-centred definition of right action, one does not, according to Hursthouse, render such an ethics less capable of guiding action than its deontological and utilitarian rivals. Consider a comparison with deontology and utilitarianism, both of which, in being actioncentred, are thereby thought to be action guiding. In deontology an action is considered right if and only if it accords with a defensible moral principle or rule, while in utilitarianism an action is right if and only if it promotes the best consequences. But, as is the case with the definition of right action in virtue ethics (viz, an action is right if and only if it is what a virtuous agent would characteristically do in the circumstances), the first premisses of any deontology and of any utilitarianism need further supplementation. In the case of deontology we need to know whether a defensible moral principle is a categorical imperative, or what is commanded by God, or the object of choice for all rational beings, etc. With utilitarianism we need to know what is to count as the best consequences; is it the maximization of pleasure, or the greatest happiness of the greatest number, or the maximization of an agent's preferences, etc. In the case of virtue ethics the needed supplementation concerns the nature of a virtue as a trait of character: is a virtue something which is agreeable and useful to its possessor (Hume), or is it something which is needed by humans to live well (Aristotle)? The upshot of this comparison, then, is that as far as action guidance is concerned, virtue ethics is no worse off than actcentred deontological and utilitarian theories.

For Hursthouse then, the agent-centred nature of virtue ethics does not automatically preclude its being action guiding. Indeed, such an ethics can, like deontology, provide action guiding rules. Thus, appeal to what any honest and compassionate agent would characteristically do can give rise to such rules as "act honestly," "act compassionately." In ordinary circumstances we know perfectly well how a virtuous agent would apply these rules. To critics of virtue based moral education such as Kohlberg, however, the chief difficulty in such an approach is not so much over the question of applying the virtues in ordinary circumstances, but applying them in hard cases where particular virtues conflict. So virtue based rules such as "act compassionately" and "act honestly" will not guide us in cases such as the woman severely injured in a car accident: do we act honestly and tell her the truth about the rest of her family or do we act compassionately and, given her fragile condition, spare her feelings and not tell her? Kohlberg's point, along with other critics of virtue ethics, is that appeal to what an honest and compassionate agent would characteristically do in such a case, will not guide us when faced with dilemmas, even if it can guide us in ordinary non-conflicting circumstances.

Whether virtue ethics can provide guidance as to what to do in hard cases depends, writes Hursthouse, on whether a dilemma is resolvable or irresolvable. With the latter, virtue ethics cannot provide guidance since a hard case in being ex bypothesi irresolvable, is one in which nothing can count as the reasonable practical answer to the question, "What ought I to do?" This, however, does not disable virtue ethics from providing assessments of possible actions even if it cannot help choose the right action. Indeed, it strikes Hursthouse as an advantage of virtue ethics that it can employ a variety of aretaic concepts in assessing actions without thereby suggesting that for every hard case there must be one action which is the right one, while all others, since they are assessed as not-right, are therefore wrong.

Even in cases where a dilemma is resolvable, virtue ethics can guide us, not necessarily to the right action, but to the right choice. For being resolvable means that a virtuous agent has reasons which determine what is the reasonable thing to do in the circumstances, However, the circumstances may be such that the undoubted reasonable thing to do is simply the undoubted best thing to do in the circumstances. In being the best thing to do one has not necessarily chosen the right action since both alternatives may be pretty bad. One has simply chosen, for reasons which for the virtuous agent are conclusive, the least bad alternative. It should be said here that Kohlberg, in using dilemmas as his chief pedagogical device, often commits what Hursthouse calls the fallacy of the false dilemma; that is, 
dilemmas are presented in a way that makes it look as if one of the two alternatives presented is the one and only one, morally right thing to do in the circumstances. This not only overlooks the difference between right choice and right action, but tends to overlook the existence of irresolvable dilemmas. Moreover, in presenting dilemmas as a fait accompli, Kohlberg's approach overlooks the fact that there are certain dilemma-creating circumstances which no virtuous agent would ever allow himself or herself to get into. Perhaps the young as part of their developing practical reason, need to learn how to recognize such circumstances and thus avoid dilemmas.

In addition to these objections to Kohlberg's use of dilemmas, Hursthouse's neo-Aristotelian discussion of the action-guiding features of virtue ethics generates at least two additional conclusions about the conduct of moral education. The first conclusion concerns the kind of knowledge a person needs to acquire so as to become virtuous. For Hursthouse a normative ethics does not provide us with a decision procedure which a reasonably clever adolescent could learn to apply in various cases. In virtue ethics, the correct application of "thick" aretaic concepts to various circumstances is difficult, and learning to do so takes time and experience. Although very early on children may learn certain virtue related rules such as "act honestly" and "act compassionately," often enough, circumstances may require one to answer questions such as, "is the truth about the death of a severely injured patient's family the sort of truth it does no kindness to hide?"; "is it the sort of truth we can avoid telling for a while since, given her present condition, we cannot set her feelings completely aside?" etc. For Hursthouse, adolescents, no matter how clever, normally do not have the judgement and discernment required to answer questions of this sort, although such abilities are necessary features of the virtuous.

The second additional conclusion about the conduct of moral education, arises because of what Hursthouse calls the moral remainder or residue. In those resolvable dilemmas where there is only a right choice but no right action, acting on the right choice would characteristically bring a virtuous agent to feel "distress or regret or remorse, or guilt, or in some cases...recognizing that some apology or restitution, or compensation is called for."(p. 44) These feelings and recognitions are the moral remainder of certain dilemmas. In cases where the dilemmas are irresolvable, feelings can range from distress to the kind of grief that can mar the life of even the most virtuous of agents. The virtues then involve both reason and emotions and therefore the fostering of the virtues requires the education of the emotions. But how are reason and emotion connected in the fully virtuous? Answering this question is central to determining how the education of the emotions is to occur.

\section{Upbringing and the Emotions}

Hursthouse begins by dismissing two views about the relation between reason and the emotions. One view, perhaps best seen as Kant's, sees the emotions as forming no part of our rational nature. On this view the emotions come from the non-rational side of our nature which, if we are lucky, prompt us to act in accordance with our reason. But if our emotions incline us against our reasonable judgements, our lives can be difficult and full of struggle. Although making the emotions completely non-rational can go some way in providing an understanding of how they can exercise a disruptive force, it does not provide any insight into how the emotions of the virtuous agent can be the correct ones to have; i.e., be the right emotions felt on the right occasions toward the right people or objects for the right reasons. On the second view, perhaps dating from the Stoics, emotions are said to be correct when the judgements which constitute them, wholly or in part, are correct. This view makes the emotions too rational and fails to provide any understanding of how an agent can recognize disparities between their judgements and their emotions. In an amusing set of examples meant to illustrate this point, Hursthouse writes: "I know perfectly well that the insect is harmless but am still terrified of it, that the tin-opener is not defying me and did not cut my thumb on purpose but am still furious with it, that my partner is a worthless skunk but I still love him, heaven help me" (p.110).

Hursthouse takes the view that whatever account of the emotions we give, it must be one which 
places them somewhere between being completely non-rational and completely rational. Hursthouse views Aristotle placing of the emotions in the desiderative part of the soul, as a satisfying way of treating this Janus-faced aspect of human emotion. For doing so renders it unsurprising that human beings can have some emotions which non-rational animals have (e.g.. fear, anger) while other human emotions non-rational animals lack (e.g. pride, shame, regret).But more importantly, such a placing allows for the transforming power of reason upon those emotions which humans share with nonrational animals. A cat may fear the advancing predator, but only a student can fear the advancing of the date of his final examinations. In human beings the "emotion that in other animals is essentially connected to physical self-preservation or preservation of the species can be transformed in human beings into an emotion connected with the preservation of what is best, most worth preserving in us and our species" (p.111).

The transforming power of reason upon emotions means that a correct human emotional response is dependent upon an agent making a correct evaluative judgement about what is worthwhile and what is not. This, however, is not the same as saying that emotions are constituted in part or entirely by such judgements, for, as Hursthouse's examples point out, emotions can occur which are out of harmony with an agent's correct evaluative judgements (e.g., being terrified of an insect one knows to be harmless). So then educating the young to become fully virtuous rather them simply continent, requires not only learning to make correct evaluative judgements which employ thick aretaic concepts, but also learning to bring emotional responses into harmony with those judgements.

No doubt most of us are familiar with Aristotle's claim in the Nicomachean Ethics (1104b11-12), that the correct education consists in having an appropriate upbringing where, even from very early youth, we learn to take pleasure and pain in the right things. In similar fashion, Hursthouse claims that if the very young have received a bad upbringing, say a racist one, overcoming the effects of this is, if not impossible, very difficult. This is due to the non-rational face of the emotions. So even if in attaining maturity, the evaluative judgements about another race that one acquired in early childhood

(e.g., they are dangerous, ignorant, perverted, etc) become recognized not only as incorrect but as irrational, this would not necessarily lead to the elimination of the racist emotional responses one learned in imitation of those who brought one up. So whether the non-rational aspect of the emotions aids or hinders the acquiring of full virtue depends very much on what we have learned to love and hate in the course of our upbringing.

\section{Upbringing and Philosophy}

Aristotle's virtual identification of a correct education with an appropriate upbringing leads to questions about what role, if any, the teaching of philosophy can have in acquiring the virtues. Would such an upbringing include philosophy as part of it? As Hursthouse points out, often in the course of raising the young, those doing so offer explanations and justifications for the various evaluative judgements they make. Thus in the case of a racist upbringing one might hear such claims as: "such people are dangerous because they can't control their passions, because they hate us, because they are cunning and devious, are not brave because they don't feel pain the way we do, do not deserve pity because they always make a fuss ..." (p. 115). However, such putative explanations and justifications normally do not count as philosophy, not even as bad philosophy. In Aristotle's own case, the teaching of philosophy presupposes that the audience to which it is directed has already had the sort of upbringing in which they have learned to love and hate the right things. Otherwise they would neither listen to nor understand what philosophy had to say about the virtues (N.E.1179b 25-30). So, in his case, philosophy is not seen as forming a part of the sort of upbringing that leads to full virtue.

What about Hursthouse's case? She says of her book that she hopes it "will be used as a textbook, helping to familiarize up-and-coming students with virtue ethics distinctive approach to a variety of problems and issues in moral philosophy" (p. 17). In the light of what she has already said 
about the time and experience necessary to learning how to apply the thick aretaic concepts employed by virtue ethics, as well as what she has said about the training of the emotions, we cannot say that she hopes her book could overcome the effects of a bad upbringing. As in the case of Aristotle's Nicomachean Ethics, Hursthouse's book does not pretend to be a substitute for the correct moral habituation of the young.

Hursthouse's enquiries about the virtues takes place in a social context quite different from that of Aristotle. Not only did Aristotle not have to consider powerful rival ethical theories such as deontology and utilitarianism, but he also did not have to deal with the diversity of ethical outlooks so characteristic of modern life. Moreover, Aristotle did not have to deal with the rather prevalent contemporary view that morality cannot be objective. In the last part of her book, Hursthouse takes on, what by her own admission is "the extremely difficult and tendentious territory of 'the objectivity (or rationality) of morality" (p.164). She does this, however, in the context of a virtue ethics, which means that instead of trying to show that certain rules or principles are objective, she indicates how we might go about showing that those qualities of character which appear on a standard list as virtues (e.g., temperance, courage, etc.) are indeed the genuine articles. Although her arguments address contemporary issues, she shares with Aristotle the idea that genuine virtues benefit those that possess them, while at the same time are the sort of qualities which we humans "are fitted by (our) nature to receive" (p.262).

While Hursthouse's book does not claim to reduce the need for a proper upbringing, does the fact of its being addressed to a contemporary student audience, whose social experience will be quite different from Aristotle's audience, mean that the book's relation to moral education will be quite different? Although differences in social context do bring about differences in some of the issues discussed, the educational function of philosophical reflection on the virtues seems to be the same; namely, to render intelligible, not only the desirability of a certain way of life but also the necessity of a certain kind of upbringing. So while philosophy may not directly contribute to its audience becoming virtuous, it can contribute to their becoming better moral educators. Hursthouse's book, while not an easy read, helps us draw a compelling picture of what a neo-Aristotelian virtue centred education would be like. 